\title{
Ginger (Zingiber officinale Roscoe) Production Efficiency and Constraints Among Small Scale Farmers in Southern Kaduna, Nigeria
}

\author{
Titilayo J. Ayodele ${ }^{1} \&$ Banake E. Sambo ${ }^{2}$ \\ ${ }^{1}$ Department of Agric. Extension \& Management, Federal College of Forestry Mechanization, Afaka, Kaduna, \\ Nigeria \\ ${ }^{2}$ Department of Crop Production, Federal University Dutse, Dutse, Jigawa State, Nigeria \\ Correspondence: Banake E. Sambo, Department of Crop Production, Federal University Dutse, P.M.B. 7156, \\ Dutse, Jigawa State, Nigeria. Tel: 234-802-330-8577. E-mail: banelisam@yahoo.com
}

Received: February 14, 2014 Accepted: May 19, 2014 Online Published: July 15, 2014

doi:10.5539/jas.v6n8p141 URL: http://dx.doi.org/10.5539/jas.v6n8p141

\begin{abstract}
Ginger (Zingiber officinale Roscoe) is mostly grown in southern Kaduna Sate, the traditional home of ginger in Nigeria. Its production was boosted with the aim of generating internal trade for the people and improved foreign exchange earnings for Nigeria. However, ginger yields in Nigeria are comparatively very low; and this is ascribed to various factors such as poor agronomic practices, unimproved varieties, laborious farming, harvesting and processing operations amongst others. It is against this background that this study carried out to examine the production, constraints and efficiency of production amongst the predominantly poor, rural farmers in the ginger production areas of southern Kaduna, Nigeria. Results showed that, the elasticity of production, farm size (1.21), ginger seed (2.19), fertilizer (0.06) and labor (0.09) are positive and had a significant effect on ginger production in the study area. The estimated coefficient of age $(0.004)$, farming experience $(-0.003)$, education (-0.02) and ginger variety (-0.28) were significant; while that of household size (0.007) was not significant. The fore-most problems affecting ginger production are risk and uncertainties $(81.56 \%)$, inadequate supply of fertilizer $(80.31 \%)$, lack of modern farm equipment $(76.25 \%)$, and lack of credit facilities $(74.1 \%)$. The technical efficiency of ginger farmers ranged between 0.74 and 1.00 ; with a mean technical efficiency of 0.82 . On the whole, this result suggests that the technical efficiency in ginger production in the area could be further increased by $18 \%$ through better use of available resources, given the current state of technology. It can be concluded that specific factors such as age, household size, year of farming experience, and the narrow gene pool (variety) of ginger planted, contributed positively to the technical and allocative efficiencies of ginger producers in the region. Ginger farmers could be said to be inefficient in the use of resources and/ or were under-utilizing their resources/input. Evidently, they can still use more resources to increase the output of ginger. Without a doubt, addressing these technical deficiencies and/ or inefficiencies could, in effect, boost ginger production, with the concomitant multiplier effect of increasing the profitability of the entire enterprise and up-liftment of the socio-economic living conditions of these predominantly, low technology base and resource poor farmers of the Southern Kaduna State, Nigeria.
\end{abstract}

Keywords: ginger, production, constraint, efficiency, socio-economic, resources

\section{Introduction}

Ginger (Zingiber officinale Roscoe) is a member of the family Zingiberaceae. Its spread has been attributed to Arab traders who took the plant from India to East Africa in the $13^{\text {th }}$ century; while the Portuguese brought it to West Africa and other parts of the tropics, in the $16^{\text {th }}$ century (Purseglove, 1976; Momber, 1942). In Nigeria, ginger cultivation started in 1927 (Arene, Orkwor, \& Okkwuowulu, 1987). It is mostly grown in southern Kaduna especially in Kwoi, Kubacha, Kafanchan and Kagarko of Kaduna State and neighboring parts of Plateau State. Indeed, its production started as a result of an investigation carried out to find a crop that would generate internal trade for the people of southern Kaduna State, the traditional home of ginger production in Nigeria (Erinle, 1987). Since then, ginger has steadily increased in importance as a valuable export commodity. However, from 1967, production declined (Arene et al., 1987). According to Meadows (1988) export trade of ginger declined due to lack of attention to the crop by the Nigerian government and due in part to trade receipts from the oil boom and to the unattractive prices it attracted. Thus, Nigeria's position in the export trade was taken by 
better placed competitors like India (Muralidhran \& Kamalam, 1973).

Ginger yields in Nigeria are indeed extremely low. Quinn (1973) quoted average yields to be about $5-12$ tonnes $\mathrm{ha}^{-1}$. But a survey conducted by Anon (1984) showed that several farms in Southern Kaduna State could only produce about $2-5$ tonnes $\mathrm{ha}^{-1}$. Yet under improved cultivation conditions, yields could be as high as 38 tonnes $\mathrm{ha}^{-1}$ elsewhere (Purseglove, 1976). It is evident that the actual yields of ginger in Nigeria fall short of the yields that are currently obtained in other parts of the world, and even short of the potential yields of the crop.

One major shortcoming of ginger production in Nigeria is the very narrow gene pool on which the industry is based. In nearly sixty years of production, farmers have relied almost exclusively on two varieties: The "Tafin Giwa" or yellow ginger and the "Yatsun Biri" or black ginger. A third variety is reported to have apparently been introduced from China (Erinle, 1987). It is worth noting that even with the existing varieties; it should be possible to increase production by improving the agronomic practices of the farmers. Tremendous losses are incurred each year by farmers who fail to mulch, weed, fertilize and harvest at the appropriate times or with the appropriate methods (Orkwor \& Melifonwu, 1988). In addition, ginger production in Nigeria is quite laborious; practically all the operations, including planting, mulching, fertilizing, weed control, harvesting, and processing are done manually (Arene et al., 1987). This of course has several adverse implications. First, it limits the hecterage that each individual farmer can cultivate. Anon (1984) reported that farmers in Southern Zaria cultivated on the average, less than one hectare. Comparatively, in Australia, planting and harvesting of the crop are completely mechanized (Purseglove, 1976). Secondly, production costs are relatively high, because of the relative high costs of labor and other inputs. In addition, weed control by means of herbicides should also be able to reduce the drudgery and intensive labor demands associated with ginger production. The large quantity of planting material required for ginger is certainly one of the uneconomic aspects of its production. It was estimated that about 1.25 tonnes of seed ginger are required to plant a hectare (National Root Crop Research Institute [NRCRI], 1987). For a crop which yields about 2 tonnes $\mathrm{ha}^{-1}$ under poor agronomic practices on farmers field; but which could yield up to 10 tonnes $\mathrm{ha}^{-1}$ if improved agronomic practices are adopted under the Nigerian growing conditions (Quinn, 1973); compared to the 23 tonnes ha ${ }^{-1}$ obtained elsewhere in Australia and India (Purseglove, 1976); this certainly represents a very low multiplication ratio.

This study therefore examined the production and efficiency of low technology and resource poor farmers in the ginger production areas of southern Kaduna, Nigeria.

\section{Materials and Methods}

Kaduna State is located between latitudes $6^{\circ} 42^{\prime} \mathrm{N}$ and Longitudes $7^{\circ} 30^{\prime} \mathrm{E}$. The State has a total population of about 6,066,562 million people (Federal Office of Statistics [FOS], 2006); comprises twenty three (23) local government areas. The highest quantity and good quality exportable ginger is grown in the Southern part of the State, which is made up of twelve local government areas out of the twenty three. These local government areas are: Chukun, Igabi, Jaba, Kafanchan, Kachia, Kagarko, Kajuru, Kaura, Kauru, Lere, Sanga and Zango-Kataf. The southern part of Kaduna is naturally endowed with favorable soils and conductive climate for the production of various crops (arable and tree crops). However, with a cultivable land area of 4.5 million hectares, only 2.02 million hectares is under cultivation. Most of the land is located in the Guinea Savannah; enjoying very adequate rainfall for farming. The annual rainfall ranges from $75 \mathrm{~cm}$ to $125 \mathrm{~cm}$, while the temperature ranges between 20 ${ }^{\circ} \mathrm{C}$ and $30{ }^{\circ} \mathrm{C}$; with a distinct dry and rainy season (Agboola, 1979; Anonymous, 2013). The soil is predominantly clay loam. The crops grown in this area includes ginger, guinea corn, millet, maize, soybean, acha, cocoyam, cassava and potatoes. The southern part of Kaduna State serves as one of the main outlet of ginger to the other parts of the country and the world (Kaduna State Agricultural Development Project [KADP], 1987).

For the purpose of this study, multi-stage sampling technique was employed across the twelve Local Government Areas making up the southern part of Kaduna State, in this study; based on their high level of involvement in ginger production activities. From the twelve, ten Local Government Areas were used, and thirty two farmers were further selected from each of them giving a total of 320 farmers. Village listing of farmers was obtained from village heads. The sample of the farmers was drawn randomly thereby giving each farmer an equal chance of being selected.

The primary data were collected with the help of trained enumerators using structured questionnaire and interviews. The questionnaire was designed to collect general information on demographic data, farm labor, farm production etc. The secondary data was collected from published data such as journals, proceeding, annual reports, textbooks, government ministries and parastatals.

Both descriptive statistics and inferential statistics were employed for the data analysis. The descriptive statistics which includes frequency distribution, percentages, and means were used to analyze the demographic and 
socio-economic characteristics of the respondents; and the production variables were analyzed using the stochastic frontier.

\subsection{The Production Function}

In the production process, it is assumed that there is a relationship between the quantity of input and the quantity of output (Heady \& Dillon, 1984; Doll \& Orazem, 1984). In mathematical terms a production function can be implicitly expressed as follows:

$\mathrm{Y}=\mathrm{F}\left(\mathrm{X}_{1}, \mathrm{X}_{2}, \mathrm{X}_{3} \ldots \mathrm{X}_{\mathrm{n}}\right)$

$\mathrm{Y}=$ physical quantity of output:

$X_{1}, X_{2}, X_{3} \ldots X_{n}=$ Physical quantity of inputs

The equation says that the quantity of output $(\mathrm{Y})$ in some unspecified mathematical function of the quantity of inputs $\mathrm{X}_{1}, \mathrm{X}_{2}, \mathrm{X}_{3} \ldots \mathrm{X}_{\mathrm{n}}$

\subsection{Technical Efficiency: The Stochastic Frontier Production Function}

Stochastic frontier production function is used to estimates the production function of the fully efficient firm (Battesse \& Coelli, 1992). Coelli (1995) presented the stochastic frontier production function as:

$$
Y_{i}=f\left(X_{i} \beta\right) \exp \left(V_{i}-U_{i}\right)
$$

Where

i. $=1,2 \ldots \mathrm{N}$;

$Y_{i}=$ the output of the $i^{\text {th }}$ farm;

$X_{i}=a$ vector of inputs;

$\beta=a$ vector of parameters to be estimated;

$\mathrm{f}=$ is a suitable functional form, such as the Cobb-Douglas or translog;

$\mathrm{V}_{\mathrm{i}}=$ are random errors that are assumed to account for measurement errors of the farm;

and,

$\mathrm{Ui}=$ are non-negative technical inefficiency in production and obtained by truncation (at zero) of the normal distribution with mean $\mathrm{u}$ and variance $\mathrm{o}^{2}$.

\subsection{Inefficiency Frontier Model}

Explicitly, the inefficiency frontier model is expressed as:

$$
\mathrm{Y}_{\mathrm{i}}=\exp \left(\mathrm{X}_{\mathrm{i}} \beta+\mathrm{V}_{\mathrm{i}}-\mathrm{U}_{\mathrm{i}}\right)
$$

$X=a(I \times K)$ vector of production inputs of the $i^{\text {th }}$ farm;

$\beta=\mathrm{a}(\mathrm{K} \times \mathrm{I})$ vector of unknown parameters to be estimated;

$\mathrm{V}_{\mathrm{i}}=$ random errors which assumed to be normally distributed with zero mean and variance $\sigma^{2}$ i.e. $\mathrm{N}\left(\mathrm{O}, \sigma^{2}\right)$;

$\mathrm{U}_{\mathrm{i}}=$ are non-negative random variables which are associated with technical inefficiency and are assumed to be independently distributed of the $\mathrm{V}_{\mathrm{i}}$. They are obtained by truncation (at zero) of the normal distribution (Coelli \& Battesse, 1996).

The inefficiency effect, $U_{i}$, is specified as:

$$
\mathrm{Ui}=\mathrm{O} \mathrm{Z}_{\mathrm{i}}+\mathrm{W}_{\mathrm{i}}
$$

Where:

$Z_{i}=(I \times m)$ vector of farm specific variables which may vary over time.

$\sigma=(\mathrm{m} \times \mathrm{I})$ vector of unknown coefficients of the farm specific inefficiency variables. The random variable Ui is defined by the truncation of the normal distribution with zero mean and variance $\sigma_{\sigma}^{2}$. The technical efficiency of production for the $i^{\text {th }}$ farm, TE is defined technical efficiency $(T E)=Y_{i} / Y^{*}$, which is the ratio of the observed output, $\mathrm{Y}_{\mathrm{i}}$ to the corresponding stochastic frontier output, $\mathrm{Y}^{*}$, where:

$$
\mathrm{Y}^{*}=\exp \left(\mathrm{X}_{\mathrm{i}} \beta+\mathrm{V}_{\mathrm{i}}\right)
$$

Which is associated with no inefficiency? Thus, technical efficiency (TE) is defined as:

$$
\mathrm{TE}=\mathrm{f}\left(\mathrm{X}_{\mathrm{i}} \beta\right) \exp \left(\mathrm{V}_{\mathrm{i}}-\mathrm{U}_{\mathrm{i}}\right) / \mathrm{f}\left(\mathrm{X}_{\mathrm{i}} \beta\right) \exp (\mathrm{Vi})=\exp \left(-\mathrm{u}_{\mathrm{i}}\right)
$$




\section{Results and Discussion}

\subsection{Ginger Production, Efficiency and Constraints}

\subsubsection{Production}

The elasticity of production result shows that at 5 percent level of significance, farm size (1.21), ginger seed (2.19), fertilizer (0.06) and labor (0.09) are positive and had a significant effect on ginger production in the study area (Table 1).

The output elasticity of farm size (1.21) and ginger seed (2.19) were greater than unity, while that of fertilizer (0.06), labor (0.09) and pesticide (0.05) were less than unity. This interpreted means that a change in the level of farm size and ginger seed will result in more than a proportionate increase in ginger output; while a change in the level of labor and fertilizer used will result in a little proportionate increase in the ginger output. Thus total output of ginger is more responsive to the level of farm size and ginger seed. This is in line with the findings of Oyewo, Rauy, Ogunwole and Balogun (2009), who observed that farm size and seeds were highly significant in determining the output of maize production among maize farmers in Ogbomosho. Similarly, Udoh and Oluwatoyin (2006) reported that farm size has the most important factor of production in a mix of farmers in Nigeria. Thus, if farmers are to increase farm revenue and net income, it is pertinent to consider farm size and ginger seed.

The sum of the coefficients (output elasticity) of the variables of the Cobb-Douglas stochastic frontier production model is 3.50 , and is greater than unity, suggesting increasing return to scale and that the farmers were under-utilizing their resources.

Furthermore, a proportionate increase in all the inputs used in ginger production would lead to more than a proportionate increase in ginger output; that is, if all inputs can be increased by $100 \%$, the output of ginger will rise by $350 \%$. This implies that expansion of ginger production in the southern part of Kaduna State, Nigeria, would result in a higher ginger output in the whole State. This means that a robust policy or collaboration between the farmer's cooperative society that would enhance the use of more production inputs by the ginger farmers in the southern part of Kaduna State would lead to an increase in ginger output and increased profitability of ginger production in the southern part of Kaduna State, region and country as a whole.

Table 1. Shows the Maximum likelihood estimate for the parameters in the stochastic frontier production function model for the ginger farmers in the southern part of Kaduna State, Nigeria, 2009

\begin{tabular}{llll}
\hline Variable & Parameter & Efficiency & T-ratio \\
\hline Stochastic Production & & & \\
Frontier & & & \\
Constant & $\beta_{0}$ & 7.37 & $41.41^{*}$ \\
Ln ( hired land) & $\beta_{1}$ & 1.21 & $2.21^{*}$ \\
Ln (seed) & $\beta_{2}$ & 2.19 & $3.97^{*}$ \\
Ln (fertilizer) & $\beta_{3}$ & 0.06 & $2.86^{*}$ \\
Ln (labour) & $\beta_{4}$ & 0.09 & $5.45^{*}$ \\
Ln (Pesticide) & $\beta_{5}$ & -0.05 & -0.94 \\
Inefficiency Model & & & \\
Constant & $\delta^{\mathrm{o}}$ & 0.27 & $2.79^{*}$ \\
Age & $\delta^{1}$ & 0.004 & $3.69^{*}$ \\
Farming Experience & $\delta^{2}$ & -0.003 & $-5.03^{*}$ \\
Education & $\delta^{3}$ & -0.02 & $-5.20^{*}$ \\
Household size & $\delta^{4}$ & 0.01 & $1.87^{*}$ \\
Ginger variety & $\delta^{5}$ & -0.28 & $-14.86^{*}$ \\
Variance Parameters & & & \\
Sigma squared & $\sigma^{2}$ & 16.84 & $12.59^{*}$ \\
Gamma & $\gamma$ & 0.93 & $2.56^{*}$ \\
Log likelihood Function & & $202.87^{*}$ & \\
\hline
\end{tabular}

Source: Field Survey, 2009.

$* \mathrm{~T}$ - ratio is significant at 5\% level. 


\subsubsection{Inefficiency in Production}

The estimated coefficient of age (0.004), farming experience (-0.003), education $(-0.02)$ and ginger variety planted (-0.28); household size (0.01) were significant at 5\% level (Table 1). This result suggests that technical inefficiency effects in ginger production in the southern part of Kaduna State, Nigeria, decreased with increase in farming experience, educational level and planting of improved ginger variety; while on the other hand, it increased with age. This means that farming experience, educational level and planting of improved ginger variety have positive effects on technical efficiency in ginger production in the area; while age has a negative effect on technical efficiency. This suggests that age, farming experience, educational level and planting of improved ginger variety are important in achieving increased ginger production in the region. In other words, farmers who are relatively younger, had long years of farming experience and higher educational level with improved ginger variety, achieved higher levels of technical efficiency in ginger production in the study area. This implies that programmes that would encourage younger ginger farmers with long farming experience and high educational level, coupled with the use of improved ginger variety for production, would ensure enhanced efficient use of resources in the ginger production process in the area. In effect, boosting production would have the multiplier effect of increasing the profitability of ginger production and up-lifting the socio-economic living conditions of these predominantly, low technology based and resource poor farmers in the Southern part of Kaduna State. Indeed, the use of more resources will further ensure the movement of the ginger farmers from the production phase of increasing return to scale to the phase of decreasing return to scale where profit is maximized.

The estimated sigma squared (16.48) was significantly different from zero at 5\% level; indicating a good fit and the correctness of the specified distributional assumption of the composite error term. In addition the magnitude of the variance ratio, $\gamma$, was estimated to be high at 0.93 , suggesting that the systematic influences that are unexplained by the production function are the dominant sources of errors. This means that $93 \%$ of the variations in inputs use among the ginger farms in the study area are due to differences in technical efficiency. Thus, the result of the diagnostic statistics confirms the relevance of stochastic frontier production function, using the maximum likelihood estimates.

\subsubsection{Production Constraints}

The top four problems affecting ginger productions are risk and uncertainties $(81.56 \%)$, inadequate supply of fertilizer $(80.31 \%)$, lack of modern farm equipment (76.25\%), and lack of credit facilities $(74.1 \%)$. The result indicated that the problems of the farmers were mostly those of inputs mobilization. This result is in consonance with Akpokodje, Lancon and Erensteinn (2002) who identified the problems of ginger farmers in Nigeria as those of access to and cost of external inputs. The high percentage of response recorded in this direction (constraints) is an indication that governmental policy interventions in the ginger industry have not yet been directed to adequately address these problems.

Table 2. presents production constraints distribution of ginger farmers in the southern part of Kaduna State, Nigeria, 2009

\begin{tabular}{lll}
\hline Constraints & Frequency & Percentage \\
\hline Inadequate Capital & 159 & 49.69 \\
Lack of Credit facilities & 237 & 74.06 \\
Lack of Modern farm Equipment & 244 & 76.25 \\
Poor Access Road & 159 & 49.69 \\
Inadequate Supply of Fertilizer & 257 & 80.31 \\
High Cost of Labour & 109 & 34.06 \\
Risk and Uncertainties & 261 & 81.56 \\
\hline
\end{tabular}

Source: Field Survey, 2009;

$(\mathrm{N}=320)$ Multiple responses.

\subsubsection{Production Efficiency Estimates for the Stochastic Frontier}

The result presented in Table 3, shows that majority of the respondents $(83.75 \%)$ operated within a technical 
efficiency range of 0.70 and less than 0.80 ; while $4.06 \%$ operated within a technical efficiency range of 0.90 and less than 1.00; and $12.19 \%$ of respondents operated within a technical efficiency of equal to 1 .

This indicates that most of the respondents operated close to their production frontier; and this could be attributed to their relatively young age, long years of farming experience, high educational levels and adoption of improved ginger varieties.

The technical efficiency of ginger farmers in the southern part of Kaduna State, Nigeria, ranged between 0.74 and 1.00; with a mean technical efficiency of 0.82 . This result suggests that technical efficiency in ginger production in the area could be further increased by $18 \%$ through better use of available resources, given the current state of technology. And this could be achieved through farmer specific factors as: age, farming experience, education and planting of improved ginger varieties.

Table 3. Shows the distribution of respondent based on technical efficiency estimates

\begin{tabular}{lll}
\hline Technical efficiency & Frequency & Percentage \\
\hline $0.70-0.80$ & 268 & 83.75 \\
$0.80-0.90$ & 0 & 0 \\
$0.90-1.00$ & 13 & 4.06 \\
1.00 & 39 & 12.19 \\
Total & $\mathbf{3 2 0}$ & $\mathbf{1 0 0 . 0}$ \\
\hline Minimum efficiency $=0.74$ & & \\
Maximum efficiency $=1.00$ & & \\
Mean efficiency $=0.82$ & & \\
\hline
\end{tabular}

Source: Field Survey, 2009.

Furthermore, the results of the frequency distribution of allocative efficiency estimates in Table 4 showed that allocative efficiency ranged from 1.00 to 1.28 ; while the mean allocative efficiency was 1.04 . The result further indicated that the average ginger farmer in the study area could enjoy a cost saving of about $3.13 \%$ if the farmer attained the level of maximum efficiency in ginger production; while the most inefficient farmer will have an efficiency gain of $0 \%$ if he/she is to attain an efficiency level of the most allocatively efficient farmer in ginger production in the study area.

Table 4. distribution of allocatie efficiency estimate of respondents of ginger production in the southern part of Kaduna State by allocative efficiency estimates

\begin{tabular}{lll}
\hline Allocative efficiency & Frequency & Percentage \\
\hline 1 & 2 & 0.63 \\
$1.01-1.10$ & 317 & 99.06 \\
$1.11-1.20$ & 0 & 0.00 \\
$1.21-1.30$ & 1 & 0.31 \\
Total & $\mathbf{3 2 0}$ & $\mathbf{1 0 0 . 0}$ \\
\hline Minimum efficiency $=1.00$ & & \\
Maximum efficiency $=1.28$ & & \\
Mean efficiency $=1.04$ & & \\
\hline
\end{tabular}

Source: Field Survey, 2009. 


\section{Conclusion and Recommedations}

\subsection{Conclusion}

Based on the findings of this study, it can be concluded that specific factors such as age, household size, year of farming experience, and the ginger variety planted, contributed positively to the technical and allocative efficiencies of ginger producers in the southern part of Kaduna State, Nigeria. Ginger farmers were inefficient in the use of resources and/ or were under-utilizing their resources/input. Evidently, they can still use more resources to increase the output of ginger; given the current state of technology. Obviously, it can be concluded that the ginger farmers in southern, Kaduna State, Nigeria, were allocatively inefficient. Without a doubt, addressing these technical deficiencies and/ or inefficiencies could, in effect, boost ginger production, with the concomitant multiplier effect of increasing the profitability of the entire enterprise and up-liftment of the socio-economic living conditions of these predominantly, low technology base and resource poor farmers.

\subsection{Recommendation(s)}

Based on the findings of the study and the conclusion arrived at, the following recommendations could be made:

(i) The ginger farmers must access improved technological packages which includes (inputs improved ginger varieties, pesticides, enhanced extension services and increase access to credits etc., to boost their productive capacities.

(ii) The ginger enterprise should be made more attractive to both the old and the young, through the invention and eventual mechanization of the production process.

(iii) The farmers should be encouraged to band themselves together - into farmers cooperative societies - to enable them pool their resources together for their own benefits of boosting productivity and increasing efficiency of production in the southern part of Kaduna, Nigeria.

\section{References}

Agboola, S. A. (1979). An Agricultural Atlas of Nigeria (pp. 1-248). Oxford University Press, London.

Akpokodje, G., Lancon, F., \& Erensteinn, O. (2003). The Nigeria Rice Economy in a Competitive World, Constraints, Opportunities and Strategic Choices; Nigeria, Rice policy and development: A Survey (p. 98). West Africa Rice Development Association (WARDA).

Anonymous. (1984). A survey of ginger production in Zone IV (p. 9). A mimeograph. Kaduna State Agric. Dev. Project, Monitoring Evaluation Unit, (KADP) Kaduna, Nigeria.

Anonymous. (2013). Vegetation. Retrieved April 21, 2013, from http://www.nig.vegetation.htm

Arene, O. B., Orkwor, G. C., \& Okwuowulu, P. A. (1987). Ginger Research in Nigeria (pp. 89-93). Proc. of the $3^{\text {rd }}$ ISTRC-AB, Ottawa, Ontario, Canada.

Battese, G. E., \& Coelli, T. J. (1992). Frontier production Functions, Technical Efficiency and Panel data: with Application to Paddy Farmers in India. Journal of Productivity Analysis, 3, 153-169. http://dx.doi.org/10.1007/BF00158774

Coelli, T. J. (1995). Recent Development in Frontier Modeling and Efficiency Measurement. Australia J. Agric. Econs., 39, 219-245. http://dx.doi.org/10.1111/j.1467-8489.1995.tb00552.x

Coelli, T. J., \& Battese, G. (1996). Identification of Factors which Influence the Technical Efficiency of Indian Farmers. American Journal of Agricultural Economics, 40, 103-128.

Dott, J. P., \& Orazem, F. (1984). Production Economics Theory with Application (2nd ed., pp. 213-215). John Willey and Sons.

Erinle, I. D. (1988). An Overview of Research of Ginger Production in the northern states of Nigeria (p. 8). A paper presented at the $1^{\text {st }}$ National Workshop on Ginger. National Root Crop Research Institute (NRCRI) Umudike, Nigeria, October $17^{\text {th }}-21^{\text {st }}, 1988$.

Federal Office of Statistics. (2006). National Population Survey (pp. 4-5). Federal Office of Statistics (FOS), Abuja, Nigeria.

Heady, E. O., \& Dillon, J. L. (1984). Agricultural Production Function. Iowa State University Press, Ames., Iowa, U.S.A. 
Kaduna State Agricultural Development Project. (1987). An Exploratory Survey of the Farming Systems of Southern Kaduna State (pp. 1-69). Kaduna State Agricultural Development Programme (KADP)/Institute of Agricultural Research (IAR), Ahmadu Bello University, Zaria, Nigeria.

Lau, L. S., \& Yotopoulos, P. A. (1971). A test for Relative Efficiency and Application to Indian Agriculture. American Economic Review 6 (pp. 67-69).

Meadows, A. B. (1988). Ginger Processing for Food and other Industry. Federal Industrial Research Organization [FIRO], Oshodi, Lagos, Nigeria.

Momber, E. N. (1942). Farm and forest. Nigerian Forester, 3, 119-121.

Muralidhran, A., \& Kanmalam, N. (1973). Improve ginger means more foreign exchange. Central Horticultural Station, Ambatayal, India. Indian Farming, 22(10), 14-15.

National Root Crop Research Institute. (1987). Ginger Production. Extension Bulletin (Vol. 15, pp. 1-6). National Root crop Research Institute (NRCRI).

Orkwor, G. C., \& Melifonwu, J. O. (1988). Critical Period for Weeds Competition in Seed Ginger Grown from Mini-Setts (pp. 136-138). National Root crop Research Institute (NRCRI) 11, Umudike, Nigeria.

Oyewo, I. O, Rauy, M. O., Ogunwole, F., \& Balogun, S. O. (2009). Determinants of Maize Production among Farmers in Ogbomosho South Local Government in Oyo State Nigeria. Agricultural Journal, 4(3), 144-149.

Purseglove, J. W. (1976). Tropical Crops, Dicotyledons (pp. 1-719). Longman Group Limited, London.

Quinn, J. G. (1973). Ginger and other Spices Report on London competence Samaru agricultural News letter (pp. 2-3).

Udoh, E., \& Oluwatoyin. F. (2006). Resource - Use Efficiency and Productivity among Farmers in Nigeria. Journal of Agriculture and Social Sciences. Retrieved from http//www.fspublihers.org

\section{Copyrights}

Copyright for this article is retained by the author(s), with first publication rights granted to the journal.

This is an open-access article distributed under the terms and conditions of the Creative Commons Attribution license (http://creativecommons.org/licenses/by/3.0/). 